1 British HIV Association (BHIVA) guidelines for the treatment of HIV-infected adults with antiretroviral therapy. London: BHIVA Writing Committee on behalf of the BHIVA Executive Committee, 2003. www.bhiva.org/ guidelines/2003/hiv/index.html (accessed 26 Apr 2004).

2 Department of Health and Human Services. Guidelines for the use of antiretroviral agents in HIV-1-infected adults and adolescents. Rockville: DHHS, 2003. www.aidsinfonih.gov/guidelines/adult/AA 111003.pdf (accessed 26 Apr 2004).

3 Ministry of Health, Republic of Uganda. Antiretroviral treatment policy. Republic of Uganda, Ministry of Health, 2003.

4 British HIV Association. New French guidelines for antiretroviral treatment. HIV Med 2000;1:133-6.

5 Enriquez M, Lackey NR, O'Connor MC, Mckinsey DS. Successful adherence after multiple HIV treatment failures. J Adv Nurs 2004;45:438-46.

6 Harrington D, Carpenter CC. Hit HIV-1 hard, but only when necessary. Lancet 2000;355:2147-52

7 Lane HC, Neaton JD. When to start therapy for HIV infection: A swinging pendulum in search of data. Ann Intern Med 2003;138:680-1.

8 Skolnik PR. HIV therapy: what do we know, and when do we know it? N Engl J Med 2003;349:2351-2.

9 Yeni PG, Hammer SM, Carpenter CC, Cooper DA, Fischl MA, Gatell JM, et al. Antiretroviral treatment for adult HIV infection in 2002: updated recommendations of the International AIDS Society-USA Panel [Corrected in JAMA 2003;11:32]. JAMA 2002;288:222-35.

10 Department of Health, South Africa. Operational plan for comprehensive HIV and AIDS care and treatment for South Africa. Pretoria: DH, 2003. www.gov.za/issues/hiv/careplan19nov03.htm (accessed 1 Sep 2005).

11 Nutbeam D. Health literacy as a public health goal: a challenge for contemporary health education and communication strategies into the 21st century. Health Promot Int 2000;15:259-67.

12 Nutbeam D, Kickbusch I. Advancing health literacy: a global challenge for the 21st century. Health Promot Int 2000;15:183-4.

13 Blumenthal RN, Gogineni A, Longshore D, Steinl M. Factors associated with readiness to change drug use among needle exchange users. Drug Alcohol Depend 2001;62:225-30.

14 Audrain J, Caminero A, Robertson A, Boyd R, Orlens C, Lerman C. Gender and ethnic differences in readiness to change smoking behaviour. Women Health 1997;3:139-50.

15 Rohren C, Corghan I, Hurt R, Offord K, Marusic A, McClain F. Predicting smoking cessation outcome in a medical centre from stage of readiness: contemplation versus action. Prev Med 1994;23:335-44.

16 Wagner G, Iguchi M, Schneider S, Scott J, Anderson D. Placebo practice trials: a tool to assess and improve adherence readiness. HIV Clin Trials 2002;3:475-83.

17 De Leon G, Melnick G, Kressel D, Jainchill N. Circumstances, motivation, readiness and suitability (the CMRS scales): predicting retention in therapeutic community treatment. Am J Drug Alcohol Abuse 1994;20:495-515.

18 Miller WR, Tonigan JS. Assessing drinkers' motivation for change: the stage of change readiness and treatment eagerness scale (SOCRATES). Psychol Addict Behav 1996;10:81-9.

19 NeffJA, Zule W. Development of a measure of treatment readiness for out of treatment drug users: psychometric properties and construct validity. Subst Use Misuse 2000;35:585-99.

20 Prochaska JO, DiClemente CC, Norcross JC. In search of how people change: applications for addictive behaviours. Am Psychol 1992;47: 1102-14.

\title{
Achieving food security in vulnerable populations
}

\section{Deborah Cohen}

Communities who rely on raising livestock are most vulnerable to hunger when drought or other disaster strikes. How can aid organisations provide effective help?

Hunger and malnutrition cause tremendous human suffering and cost developing countries billions of dollars in lost productivity and national income. The number of hungry people in the world rose to $852 \mathrm{mil}-$ lion between 2000 and 2002, up by 18 million from the mid-1990s, and the total number of hungry people in sub-Saharan Africa is 203 million, a third of the population. ${ }^{1}$ The human and economic costs of hunger will increase if the trend is not reversed. I visited northwest Kenya to see how organisations work to try to improve food security in pastoralist communities.

\section{Food security}

The 2004 annual report from the Food and Agriculture Organization says that little is done globally to fight hunger, although the resources needed to combat it are small compared with the benefits. ${ }^{1}$ Every dollar invested in reducing hunger can give from five to over 20 times as much in benefits. The report recommends giving priority to actions to improve food security.

But food security is a complex issue. A country or region is food secure when: "All people, at all times, have both physical and economic access to sufficient food to meet their dietary needs for a healthy and productive life." ${ }^{2}$ Food security depends principally on three variables: availability of food, access to food and a nutritious diet, and proper use of food to ensure maximal nutrition and hygiene. ${ }^{3}$ In turn, each of these variables is influenced by several factors, the most important of which is poverty; others include the national and international economic environment,

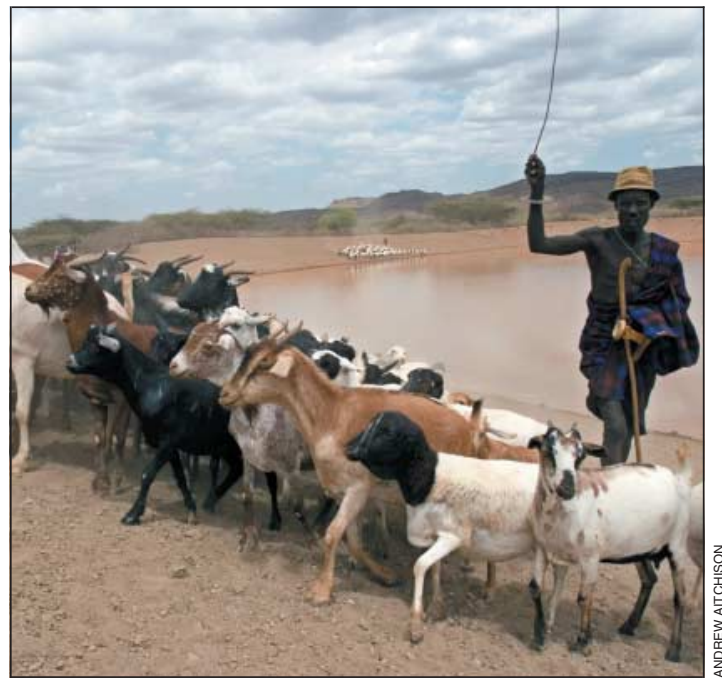

$B M J$, London WC1H 9JR Deborah Cohen assistant editor dcohen@bmj.com BMJ 2005;331:775-7

Kaeris reservoir was built by the community to store drinking water for animals

population growth, infrastructure, the climate, the level of investment and donor commitment, access to appropriate training and job skills, asset base, conflict and access to pasture, and the quality of diet, health, and sanitation.

Because of the number of influencing factors, a multilateral approach involving both the international community and national governments is needed. Some factors, such as economic conditions and infrastructure, are the responsibility of national governments and the international community as a 
whole. Others, such as climate, seem to be beyond control. But droughts are a predictable natural phenomenon and should not result in scenes such as those witnessed in Niger this year. About eight million people risked dying from starvation in one of the worst food crises to hit Africa. The food shortages followed severe drought and locust swarms in the area last year, devastating crops and livestock. ${ }^{4}$

The US Agency for International Development, Famine Early Warning Systems Network, warned about an impending food crisis eight months before the television cameras focused on the wasted bodies of dying children. As Grainne Moloney, Oxfam's regional nutrition and food security coordinator for Horn, East, and Central Africa says: "Niger represents a failure of the international community to act." But funds for long term development projects are much harder to attract. ${ }^{5}$

Because the situation in Niger had become so critical, emergency food aid from donors was the best way of providing food for the community. Yet, emergency food aid is not a long term solution to food security. It's expensive, not reliable enough, and can adversely affect local food production through depressing market prices and discouraging local production. Another criticism is that it creates dependency-a contentious issue that non-governmental organisations have differing perspectives on.

\section{Need for a broader approach}

To have a sustained effect on food security, food aid should be part of a broader effort by nongovernmental organisations and the recipient country. ${ }^{3}$ Programmes should aim to maintain food security after the non-governmental organisations leave. ${ }^{3}$ As the Food and Agriculture Organization report puts it, we have "Ample evidence that rapid progress can be made by applying a twin-track strategy that attacks both the causes and the consequences of extreme poverty and hunger. Track one includes interventions to improve food availability and incomes for the poor by enhancing their productive activities. Track two features targeted programmes that give the most needy families direct and immediate access to food."

Some communities are more susceptible to food insecurity than others. By the nature of their lifestyle, pastoralists tend to be the most vulnerable to extreme weather conditions. Their main source of income and nutrition is their livestock, which depend on pasture and water and, thus, weather conditions. During the wet seasons, when pasture and water sources are abundant, the local markets are thriving and livestock prices are favourable. Once drought hits and pasture and water sources become depleted, people sell their livestock to raise money to buy food. The sudden glut of livestock on the market, coupled with leaner livestock, means prices fall and people have less money to buy food for the droughts.

One method that non-governmental organisations use to overcome this problem is to purchase the livestock at high prices and sell the meat at subsidised prices. Although such interventions might ensure pastoralists can survive the drought, they too are emergency strategies. A recent editorial in the Economist suggests that projects offering cash or vouchers in return for work provide a solution for food security. ${ }^{5}$ These

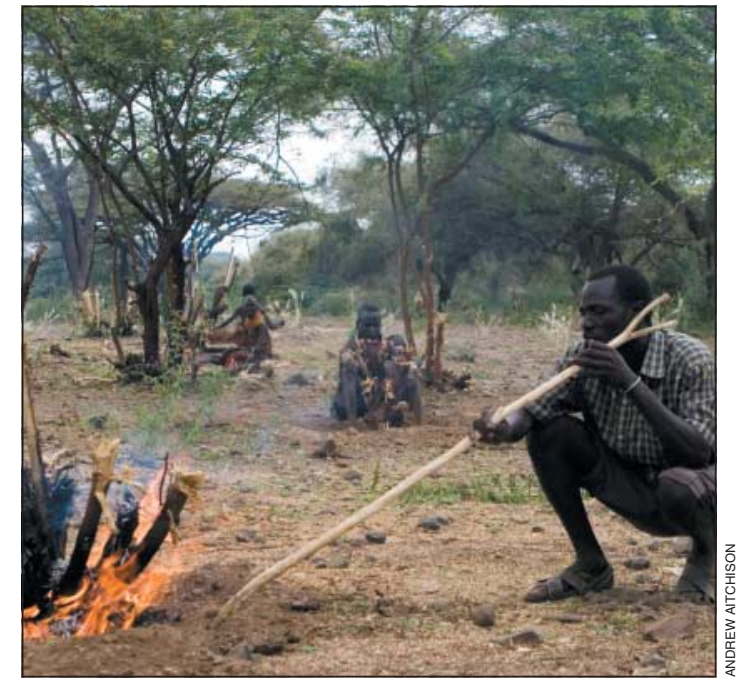

Burning Prosopis bushes

schemes, often funded by non-governmental organisations, pay local people to work on a project to generate cash and help them build up their assets.

But these schemes need to be well thought out. The Turkana, a pastoralist tribe in Kenya, refer to foreign aid workers and their government as ngimoi (enemies or strangers) after being beneficiaries of poorly planned charitable projects. ${ }^{6}$ For example, the Australian government initiative funded planting of the drought resistant shrub Prosopis. Not only does the shrub kill livestock, it is a breeding ground for mosquitoes, the thorns cause severe wounds in people, and the bushiness adds to local insecurity by providing cover for bandits. Removal of this shrub now forms an aspect of an Oxfam cash for work scheme. As Akabwai points out, local recipients need to be involved from the outset, and agencies should tap into their knowledge and customs rather than deciding their fate for them.

One of the benefits of cash for work schemes is that they allow people to make decisions independently. Lopua Lokou, one of the beneficiaries of a tree planting project after losing livestock to bandits, says: "This is a better source of assistance. I want to earn money to start a small trade--selling sugar and salt-and also buy some goats."

Projects need to tap into the community too. In Turkana district, the non-governmental organisations approach vulnerable communities and ask them to prioritise their needs and to nominate the most vulnerable members of the community to work. These tend to be people with lots of dependants, single mothers, and those with no livestock. Projects vary according to need-for example, building a water pan to collect and store rainwater for the dry season or building fences to protect against bandit attacks and cattle rustling.

\section{Role of conflict}

The Turkana's proximity to the pasture lands of neighbouring ethnic groups, coupled with the increased competition for food and water through more frequent droughts, puts them at particular risk of conflict and cattle raids. This adds to food insecurity through loss of livestock and by putting richer pastures and fish abundant parts of Lake Turkana out of bounds. A local 
peace building group, Riam Riam-Turkana for coming together-initiates negotiations about access to land between neighbouring ethnic groups. Without such initiatives, non-governmental organisation projects are jeopardised-conflict is one of the main reasons for food insecurity.

In turn, some projects help assuage the risk of hostilities. Akom Esekon, a committee member of the Kaeris water pan project, says: "Most of the community had moved away to find water. Now the community has moved back, and people are no longer forced to go on to Dassenach [Ethiopian ethnic group] territory. This means we're less at risk of conflict and cattle raids."

\section{Getting the most from cash for work schemes}

Other schemes work to directly enhance the economic profile of the surrounding area, such as by creating a market place. Margaret Lokoel, one of the beneficiaries of such a scheme in Lokitaung, a larger settlement in northern Turkana, says that she hopes the sale yard will boost the local economy and reduce poverty. "It will attract traders from outside. People will be able to set up other businesses to cater for the needs of the traders," she says. "The community will grow, and this might then encourage the government to invest in health and education." Despite this optimism, poor roads continue to hamper economic activity by making it difficult to get goods to the market. The Turkana lack a political presence in government to lobby for better roads and infrastructure, although non-governmental organisations that work closely with the community, lobby on their behalf.

Cash for work schemes have other pitfalls. The money is intended to be used to buy assets to support long term development and not to be a quick fix. However, if people don't receive food while they are working, they have to use their salaries to buy food rather than assets. For people to get the most out of these schemes, projects need to be coupled with food aid.

They also need to be supplemented by education programmes. One concern is that land management is non-existent in pastoral districts, leading to accelerated land degradation and raising questions about the viability of pastoralism as a livelihood. Pastoralists may need to diversify, as dependence on a single enterprise has made them more vulnerable to food insecurity. ${ }^{8}$ If people have resources and other skills, they are better able to cope with adverse conditions.

Several non-governmental organisations in Turkana support mobile schools to teach other skills, such as literacy. They also teach sanitation and hygiene, which improves nutritional status and influences food security by improving health. In Kenya, provision of primary education boosts food security and helps to prevent malnutrition because the government supplies primary schools with free food.

But education should not just focus on children. If market places are developed, sellers need educating about marketing livestock, how to invest the money earned from cash for work schemes, and how to diversify trade and open up businesses. Organisations such as Merlin, Oxfam, and World Vision also provide education for influential members of the community, such as traditional birthing assistants, nurses, and patient

\section{Summary points}

Food aid is necessary to meet crises but is not the most effective way of providing long term support

Programmes should aim to maintain food security after the non-governmental organisations leave

Long term strategic planning and sustainability is crucial

Non-governmental organisations, international donors, national governments, and local communities need to work together

Cash for work schemes need to be coupled with food aid

attendants. With the right training, they can promote hygiene and sanitation in their communities, recognise outbreaks of disease, and learn when people need referral to medical services.

Healthcare also needs investment. The relation between health and food security is complex. Not only can medical services treat severely malnourished people, they can stop illnesses from becoming prolonged, which affects the ability to work. If people are unable to look after their livestock and crops or are unable to search for wild fruits, they become more vulnerable, further compromising food security and health.

\section{Sustainable solutions}

If food insecurity is going to be overcome, the focus needs to shift away from emergency measures and last minute appeals for money. What's more, investment in early warning systems will not work unless national governments and the international community respond to the information.

Food security is a complex problem. Patching up the problem with goodwill isolated interventions without consulting the local community is prone to failure. A coordinated, multistranded approach is needed involving organisations from different sectors. Ultimately, improving food security will help governments achieve the millennium development goals. Not only will it help to eradicate hunger, it will help to reduce child mortality and improve maternal health. But, most importantly, it will help to break the cycle of poverty.

Competing interests: DC's trip was organised, but not subsidised, by Oxfam.

1 Food and Agriculture Organization. The state of food insecurity in the world. Rome: FAO, 2004. www.fao.org/documents/show_cdrasp?url file $=/$ docrep/007/y5650e/y5650e00.htm (accessed 20 Sep 2005).

2 US Agency for International Development. Policy determination: definition of food security. Washington, DC: USAID, 1992. www.usaid.gov/policy/ of food security. Washington, DC: USAID,
ads/200/pd19.pdf (accessed 20 Sep 2005).

3 US Agency for International Development. Food aid and food security policy

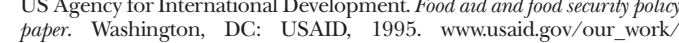
paper. Washington, DC: USAID, 1995. www.usaid.gov/our_wo
humanitarian_assistance/ffp/pnabu219.pdf (accessed 20 Sep 2005).

4 Odigwe C. Aid agencies appeal for help against famine. BMJ 2005;331:255.

5 Hunger in Niger. Economist 2005 Aug 18

6 How to make aid work. Economist 1999 Jun 24. www.economist.com/ displayStory.cfm?Story_ID = 215635 (accessed 20 Sep 2005).

7 Akabwai DMO. Extension and livestock development: experience from among the Turkana pastoralists from Kenva. London: Overseas Development Institute, 1992. www.odi.org.uk/pdn/papers/33b.pdf (accessed 20 Sep 2005).

8 FEWS Net. Kenya monthly food security update: August 17, 2005. www.fews.net/centers/innerSections.aspx?f $=\mathrm{ke} \& \mathrm{~m}=1001709 \&$. pageID $=$ monthliesDoc (accessed 20 Sep 2005). 